\title{
LEARNING MANAGEMENT SYSTEM DEVELOPMENT WITH APPLICATION OF ASYNCHRONOUS LEARNING METHOD IN STMIK IBBI MEDAN
}

\author{
Marwa Halim \\ Master Program of Information Technology \\ Binus Graduate Programs \\ Bina Nusantara University \\ Jakarta 11530, Indonesia \\ Email: marwa127@yahoo.com
}

\author{
Suharjito \\ Master Program of Information Technology \\ Binus Graduate Programs \\ Bina Nusantara University \\ Jakarta 11530, Indonesia \\ Email: suharjito@binus.edu
}

\begin{abstract}
This article will explain asynchronous learning system using attractive discussion forums and video teaching materials features for user so that the development of both features will increase e-learning system usage by students and lecturers which can eventually improve the students' absorption on the provided teaching materials, increase the active participation of students, improve self-learning ability, and to improve the quality of learning materials. The method used in this study by distributing questionnaires in online form to stakeholders users consisting of lecturers and students with the number of respondents is $\mathbf{2 2 5}$ people and author use model ADDIE which focuses on Analysis, Design, Development, Implementation and Evaluation as development design. Results of this study is an application of web-based asynchronous learning which can be used by students and lecturers with the results of the application evaluation is based on a survey to students and lecturers. From this study, can be concluded that to support online learning with asynchronous method using the video learning feature in online lecture needs to be developed in order to support the science transformation process from lecturers to students. Attractive video teaching materials model for students has characteristics such as screen shots and presentation models.
\end{abstract}

Keywords: E-learning; Asynchronous; Discussion forums; Instructional videos

\section{INTRODUCTION}

E-learning requires strong support in the aspects of information and communication technology. In the process, the teaching materials may be delivered synchronously or asynchronously [1]. For the two delivering methods, an Learning Management System (LMS)

Received: August 3, 2015; received in revised form: August 31, 2015; accepted: September 10, 2015; available online: September $30,2015$. that capable to provide learning contents in the forms of texts, discussion forum, multimedia, video and audio is indispensable.

Generally, the LMS system should contain the standard features of the following: the feature of learning materials including a list of subjects and their categories, syllabus, course materials (text-based or multimedia) and library materials; the feature of discussion and communication including discussion forum, mailing list, instant messenger, announcements, instructor's profile and contact, and file and directory sharing; and finally, the feature for exams and assignments including assessment [2].

E-learning using asynchronous process has been evolving relatively rapidly from one-to-one communication using telegraph and telephone landline to one-to-many using broadcast television and radio [3]. Recently, the process can be done simultaneously or many-to-many communcation through an Internet network using social media such Facebook, Twitter, and Google+ [4].

The asynchronous e-learning proces provides a tremendous learning opportunity and power to the end user, i.e., the learner $[5,6]$. In order to realize and implement the students' design paradigm, to reflect on the needs of learners, and to understand their attitude, we have to focus on design techniques and guidelines of LMS including the aspects of perceptions of learners [7, 8].

The most widely used learning technology architecture is the Learning Technology Systems Architecture (LTSA). LTSA is an architecture that describes the design of high-level systems and their components. 
Cite this article as: Marwa Halim and Suharjito, "Learning Management System Development With Application of Asynchronous Learning Method in STMIK IBBI Medan", CommIT (Communication \& Information Technology) Journal 9(2), 83-90, 2015.

LTSA covers the system that has been developed and known as a technology learning, education and training technology, computer-based training, computer assisted instruction, intelligent tutoring, metadata, and so on. LTSA consists of five layers that can be seen in Fig. 1.

Each layer represents a system at different level. Higher layer has a greater priority and influential in the analysis and design system [9].

Although there are various of learning media, in reality, the deployed learning media by teachers in schools is often limited. Some of the most popular learning media are printed media such as books, drawings, and models, and overhead projector and real objects. While other media such as audio cassettes, video, VCD, slide (film frame), computer learning program are rarely used despite the fact that they are common to most teachers. Some of the learning media are presented in Table I.

\section{METHODS}

A number of data was collected to understand the used features and learner usage of the asyncronous learning system. The data sources were the lecturers and students at STMIK IBBI in Informatics and Information System study program for 2013-2014 school

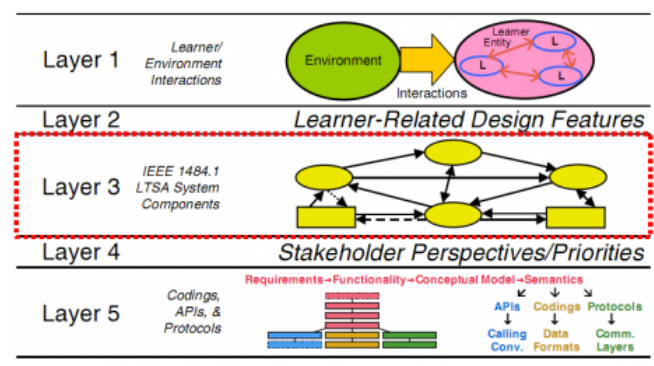

Fig. 1. LTSA Architecture Layers.

TABLE I

A NUMBER OF GROUPS OF EDUCATION MEDIA.

\begin{tabular}{|c|c|}
\hline Group & Media \\
\hline Audio & Audio Cassettes, radio, $\mathrm{CD}$, phone \\
\hline Print & Textbooks, modules, brochures, leaflets, image \\
\hline Audio-print & Audio Cassettes which include written material \\
\hline $\begin{array}{l}\text { Silent Visual Pro- } \\
\text { jections }\end{array}$ & Overhead transparency $(\mathrm{OHT})$, Movie frame (slide) \\
\hline $\begin{array}{l}\text { Silent Audio visual } \\
\text { Projections }\end{array}$ & Voiced movie frame (slide) \\
\hline Movement Visual & Silent movie \\
\hline Audio & $\begin{array}{l}\text { Visual motion, motion picture sound, video/VCD } \\
\text { television }\end{array}$ \\
\hline Physical Object & Real Objects, models, specimens \\
\hline $\begin{array}{l}\text { Human and Envi- } \\
\text { ronment }\end{array}$ & Teacher, Librarian, Laboratory \\
\hline Computer & $\begin{array}{l}\text { CAI (Computer Assisted Instruction), CBI (Com- } \\
\text { puter Based Instruction) }\end{array}$ \\
\hline
\end{tabular}
year from the first to the sixth semesters. The number of participants was 225 persons consisting of 25 lecturers, 100 students majoring in Information Systems, and 100 students majoring in Engineering Informatics. Among those lecturers, 10 have background in scientific programming, 10 in general use of computers, and 5 in science.

The obtained data were analyzed qualitatively with the following process. The first phase is data reduction where the data were sorted into relevant, important, meaningful, and useful data to explain what happened to the student in the learning process. The second phase provides description which can be a narrative, drawings, tables for easy reading. The third phase involves inference from the data for the impact of the use of learning media. The last was an quantitative analysis where the data were analyzed to understand the percentage of learning material absorption and presentation. The research procedure is depicted in Fig. 2

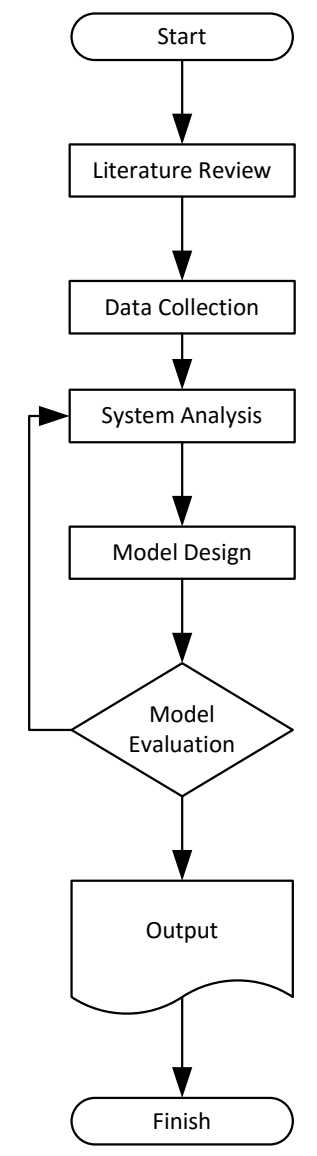

Fig. 2. The research procedure. 
Cite this article as: Marwa Halim and Suharjito, "Learning Management System Development With Application of Asynchronous Learning Method in STMIK IBBI Medan", CommIT (Communication \& Information Technology) Journal 9(2), 83-90, 2015.

\section{RESULTS}

In the following, we describe the results of participant responses with respect to the questions described in Table II. Those questions were about the necessary features to support e-learning, the use of e-learning to improve learning quality, the necessity of digital repository, the need of high-speed internet access, and the use of information technology to facilitate learning process.

The participant responses to the question that LMS supporting learning and necessary LMS features are presented in Table III.

The results suggest that the majority of the respondents agree that LMS is important to support learning. An amount of $54 \%$ agree that e-learning improves learning quality. The feature of digital repository system is essential for e-learning and is supported by $55 \%$ of the respondents. Forty-nine percents agree that highspeed Internet access is important. Majority believe that e-learning helps student learning.

Five were provided to understand the importance of video feature in LMS. Those questions were about the importance of video usage for learning, type of video presentation, and instructional video. The results from the 225 respondents are summarized in Table V.

The respondent's responses regarding the video feature are of the following. Sixty-one percents strongly agree that the video feature is crucial for helping learning. Fifty-two percents agree that instructional

TABLE II

THE EVALUATED VARIABLES AND THE NUMBER OF RELATED QUESTIONS.

\begin{tabular}{lc}
\hline Variables & Number of Items \\
\hline Features supporting e-learning & 6 \\
Video feature & 5 \\
Online chatting feature & 4 \\
\hline
\end{tabular}

TABLE III

THE RESPONSES FOR THE QUESTION OF FEATURES SUPPORTING E-LEARNING.

\begin{tabular}{|c|c|c|c|c|c|c|}
\hline Questions & SA & MA & A & LA & SNA & Total \\
\hline E-learning improves learning quality & 121 & 31 & 45 & 20 & 8 & 225 \\
\hline $\begin{array}{l}\text { The university should provide a digital } \\
\text { repository }\end{array}$ & 124 & 38 & 38 & 18 & 7 & 225 \\
\hline The speed of access is very important & 110 & 45 & 41 & 21 & 8 & 225 \\
\hline $\begin{array}{l}\text { E-learning system helps students learn- } \\
\text { ing }\end{array}$ & 115 & 55 & 23 & 19 & 13 & 225 \\
\hline $\begin{array}{l}\text { Using e-learning system, the daily } \\
\text { face-to-face session with teacher is not } \\
\text { required }\end{array}$ & 110 & 45 & 40 & 25 & 5 & 225 \\
\hline $\begin{array}{l}\text { To use of information technology for } \\
\text { learning is crucial for teachers and stu- } \\
\text { dents }\end{array}$ & 117 & 46 & 54 & 8 & 0 & 225 \\
\hline
\end{tabular}

video is important, and fifty-five percents agree that video screen shoot model is also important.

Four questions were provided to understand the respondent opinions regarding the importance of the chat feature in LMS. Those question can be seen in Table V.

The participant responses regarding the use of chat feature are: The chat feature is crucial for obtaining relevant learning material (strongly supported by $40 \%$ of the participants), is important to improve student learning (strongly supported by $51 \%$ of the participants), and is important for ICT-based learning (strongly supported by $60 \%$ of the participants), and is important to facilitate discussion (strongly supported by $59 \%$ of the participants).

The use case is a pattern or a picture that shows the system behavior or habits. The use case diagram describes the expected functionality of a system that emphasizes on "what" made the system, and not "how" a user interacts with the system. Figure 3 shows the use case diagram for the learning management system. In the use case diagram shown in Fig. 3, there are some additional modules from the old system. Added modules are marked with red color use case consists of videos upload and teaching materials upload carried by academic actor, while the students and faculty can view videos that have been uploaded by the academic.

TABLE IV

THE RESPONSES FOR THE QUESTION OF VIDEO FEATURE TO SUPPORT E-LEARNING.

\begin{tabular}{lcccccc}
\hline $\begin{array}{l}\text { The use of video facilitates understand- } \\
\text { ing of e-learning process }\end{array}$ & 137 & 50 & 17 & 12 & 9 & 225 \\
$\begin{array}{l}\text { The use of video makes e-learning eas- } \\
\text { ier }\end{array}$ & 116 & 58 & 34 & 17 & 0 & 225 \\
$\begin{array}{l}\text { The use of video presentation helps stu- } \\
\text { dents understanding learning materials }\end{array}$ & 116 & 34 & 30 & 19 & 26 & 225 \\
$\begin{array}{l}\text { The use of video increases student per- } \\
\text { formance }\end{array}$ & 121 & 58 & 21 & 7 & 18 & 225 \\
$\begin{array}{l}\text { The use of video makes learning soft- } \\
\text { wares easier }\end{array}$ & 123 & 64 & 13 & 25 & 0 & 225 \\
$\begin{array}{l}\text { SA = Strongly Agree, MA = Mostly Agree, A = Agree, LA = Less } \\
\text { Agree, SNA = Strongly Not Agree }\end{array}$ & & & & &
\end{tabular}

TABLE V

THE RESPONSES FOR THE QUESTION OF THE IMPORTANCE OF CHAT FEATURE IN THE LEARNING MANAGEMENT SYSTEM.

\begin{tabular}{lllllll}
\hline $\begin{array}{l}\text { The chatting feature on e-learning sys- } \\
\text { tem facilitate students and teachers in } \\
\text { exchanging learning materials }\end{array}$ & 91 & 50 & 63 & 12 & 9 & 225 \\
$\begin{array}{l}\text { The use of chatting feature improves } \\
\text { student performance }\end{array}$ & 114 & 49 & 31 & 30 & 1 & 225 \\
$\begin{array}{l}\text { Using e-learning system, the chatting } \\
\text { feature is necessary }\end{array}$ & 135 & 40 & 30 & 13 & 7 & 225 \\
$\begin{array}{l}\text { The chatting feature facilitates discus- } \\
\text { sion between teachers and students } \\
\text { about learning materials effectively and } \\
\text { efficiently }\end{array}$ & 132 & 42 & 29 & 21 & 1 & 225 \\
\hline $\begin{array}{l}\text { SA = Strongly Agree, MA = Mostly Agree, A = Agree, LA = Less } \\
\text { Agree, SNA = Strongly Not Agree }\end{array}$ & & & & & &
\end{tabular}


Cite this article as: Marwa Halim and Suharjito, "Learning Management System Development With Application of Asynchronous Learning Method in STMIK IBBI Medan", CommIT (Communication \& Information Technology) Journal 9(2), 83-90, 2015.

Besides, lecturers and students can also perform chatting. Figure 4 shows the class diagram of the system.

\section{A. Evaluation}

To evaluate the STMIK IBBI online learning system http://www.online.stmikibbi.ac.id using PIECES methods (Performance, Information, Economic, Control, Efficiency And Service) as a basis for obtaining a clearer and specific evaluation regarding STMIK IBBI online learning system, which is also expected to assist in the development of STMIK IBBI online learning system. PIECES method is as follows:

1) Performance Evaluation. Performance evaluation is the ability to complete business tasks quickly so that objectives can be achieved. Performance is measured by the amount of production (throughput) and response time of a system. Total production (throughput) is the amount of work that can be completed during a specific time. Response time (response time) is the result of the evaluation done by the author based on performance regarding STMIK IBBI online learning system as follows:

- Total Production (Throughput). Throughput generated by STMIK IBBI online learning system is very large as the information storage process on teaching activities undertaken in STMIK IBBI were done through a dynamic website, which provides information

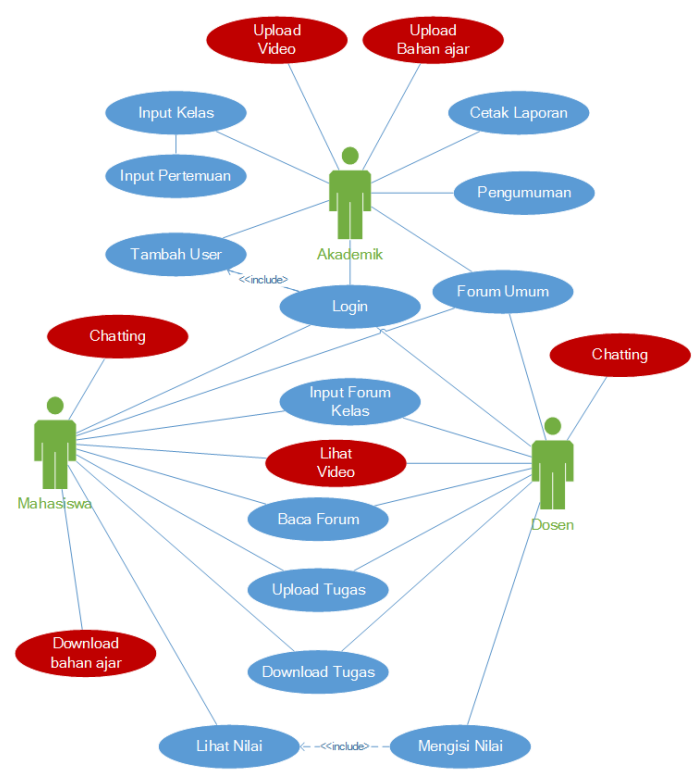

Fig. 3. The use case diagram for the development of a learning management system. that can be accessed anytime and anywhere, but from the design view, there are too many link that uses an big size image which is a wastage on online page design learning system itself. For the amount of throughput used in each semester range from about 19 classes where each class should have 16 meetings and in one session the lecturer and student must give minimum of 3 posts and 2 comments so if totaled, it would be about 29232 number of posts. In the second semester, it has about 19152 number of posts.

- Response time. STMIK IBBI Online learning system become a very effective media in disseminating information on various aspects, to all lecturers and students in general. Speed (Response time) in STMIK IBBI online learning system access is also quite fast, the main view in the whole is pretty good.

2) Information Evaluation. Information is assessing whether current procedures still could be improved for a better information quality. Which mean increasingly relevant, accurate, reliable, complete and on-time information. Evaluation of STMIK IBBI online learning system ability in generating useful information needs to be done to address the opportunities and issues that often arise. In this case improving information quality is not mean to increase information amount, as too much information will create new problems. Results of the evaluation conducted by the authors on STMIK IBBI online learning system site i.e.,

- Information/Data Relevant. With STMIK IBBI online learning, it will help the student greatly in obtaining information and facilitate the students learning process to do tasks given by lecturer. Informations are available for the students in the form of teaching materials, videos and discussion with faculty and fellow students in a chat forum.

- Information Accuracy. STMIK IBBI Online learning system provide information on all STMIK IBBI learning activities. Ranging from information as an information tool in the form of announcements or internal STMIK IBBI news-related such as announcements of the STMIK IBBI academic and others. This is one of the services provided by STMIK IBBI as one of the effective means of communication to reduce 
Cite this article as: Marwa Halim and Suharjito, "Learning Management System Development With Application of Asynchronous Learning Method in STMIK IBBI Medan”, CommIT (Communication \& Information Technology) Journal 9(2), 83-90, 2015.

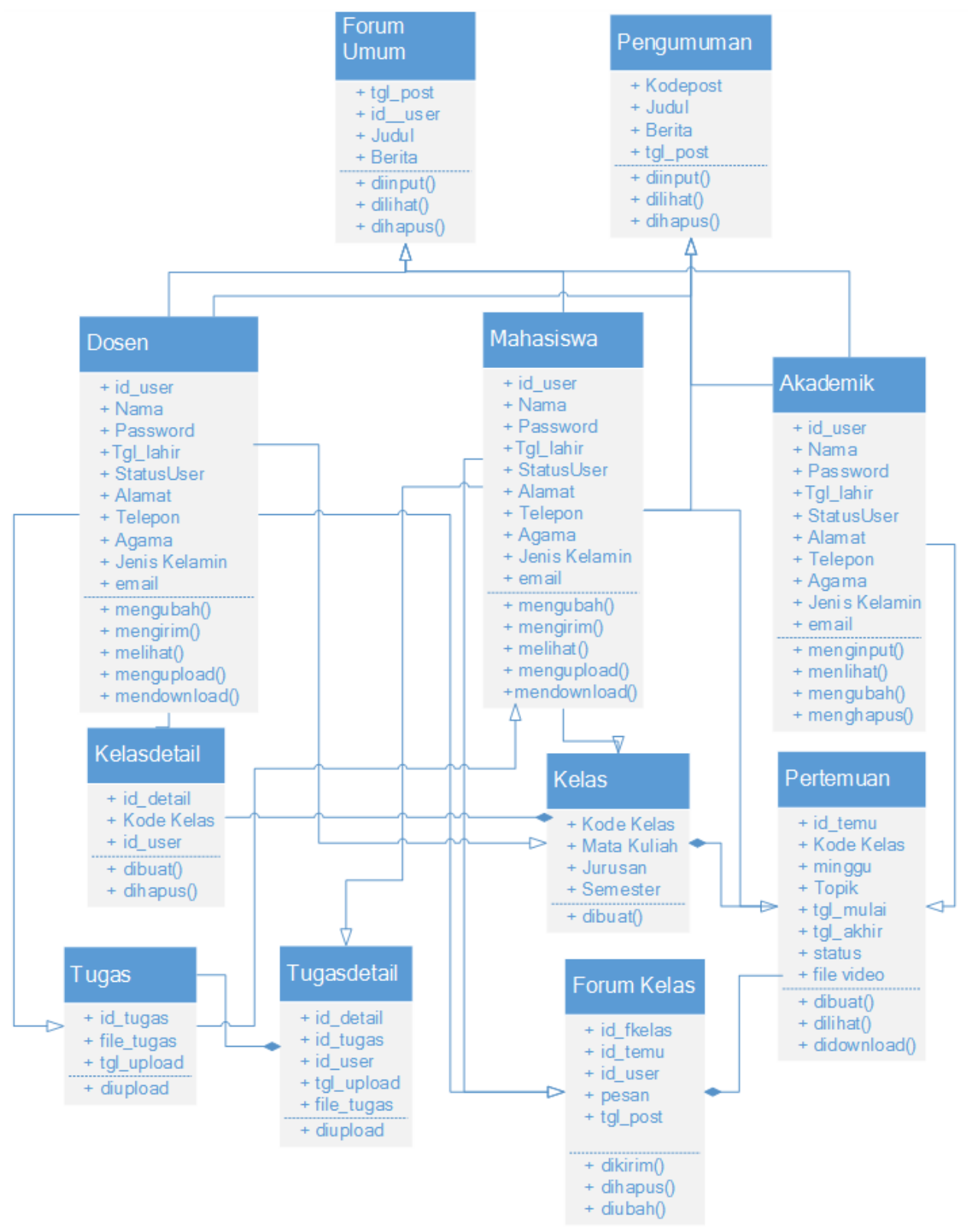

Fig. 4. The class diagram development of the system.

the use of paper or paperless. Academic section who entitled CRED (Create, Read, Edit, Delete) on the announcement to display the announcement can be seen in the picture below.

- Completeness of Information. Presentation of information on STMIK IBBI online learning system is done thoroughly, ranging from giving assignments from various courses, presentation of student and lecturer profiles, news facilities and so forth. So as to help students in the learning process. In addition to the above information, students can immediately see their score for the task that has been given. Score display can be seen in the picture below.

- Reliability. In terms of information delivery functions, STMIK IBBI online learning system provide easy access for anyone who needs no matter wherever they are. So its main purpose as a medium of learning and appropriate information can be imple- 
Cite this article as: Marwa Halim and Suharjito, "Learning Management System Development With Application of Asynchronous Learning Method in STMIK IBBI Medan", CommIT (Communication \& Information Technology) Journal 9(2), 83-90, 2015.

mented.

- Punctuality. With STMIK IBBI online learning system, important information conveyed to the student in time. Which of course would be very useful and beneficial.

3) Economic (Economy Evaluation). Economic evaluation is always associated with the presence of a budget or costs, economic analysis is related to learn and apply its costs and benefits. The cost here is not only in financial terms but also in non-financial.

In this era of developing information technology, the manufacture of STMIK IBBI online learning system facilitate student and faculty to access the latest news and providing to online learners. So that faculty and students do not spend another trip cost to the campus while the college can savings room, electricity, air conditioning and more when compared to conventional learning in the classroom.

4) Security (Security Analysis). Security analysis is the increase of the controls to detect and correct faults and deficiencies that will happen. Control system is indispensable existence to avoid and detect abuse or error in the system and ensure the security of data and information. With the security, then all impaired performance can be quickly repaired. Results of the evaluation made by the author on STMIK IBBI online learning system based on security are as follows:

- Error prevention process is quite effective and practical. The existence of STMIK IBBI online learning system in the current operation is certainly ease STMIK IBBI to control, because the delivery of information and publications in STMIK IBBI online learning system managed by STMIK IBBI academic data division. So the error information and publications in STMIK IBBI online learning system can be revised directly.

- Input validation activities, the output process is adequate. STMIK IBBI online learning system become a medium to deliver information that is highly effective in the continuity of STMIK IBBI teaching and learning activities. For that, security warranty in data and information control for STMIK IBBI online learning system which owned by STMIK IBBI be the utmost priority to avoid the system abuse.

5) Efficiency (Efficiency Evaluation). Efficiency evaluation is an increase in the operational, in contrast to the economy. When the economy related to its input, the efficiency is related to how those resources are used to avoid wastage. System is considered to be efficient or successful if it can achieve the desired goals, that does not spend a lot of redundant time and manpower. This relates to a current system running on STMIK IBBI.

With the additional media information such as STMIK IBBI online learning system, is expected to increase the conveyed information quantity, and in a fast, clear and concise delivery time. So it is very time efficient for students and lecturer in STMIK IBBI.

6) Services (Service Evaluation). Service evaluation is improvement of the services produced by a system. The system which currently being run or used STMIK IBBI aims to improve the service performance in deliver information from faculty to students and the opposites, despite of space and time, and information can also be accepted to the fullest.

\section{B. Success Rate}

Based on the evaluation that has been done, it is necessary to do a further measurement on result evaluation of whether STMIK IBBI online learning system has been able to increase the absorptive capacity of the students on the material being taught, increase the active participation of students, improve self-learning ability, and improve the quality of learning materials.

In this study, to measure the success level of STMIK IBBI Medan online learning information systems, is by looking at the score results of second semester students for the academic year 2013-2014 before the online learning information system compared with students in the same half of the school year 2014-2015 in the subject of the Commercial Package II for the second semester. The number of students involved in this study involving 70 students for the course Commercial Package II program for the academic year 2013-2014 and for the 2014-2015 school year involving 76 students for the same courses.

Based on the score recaps results for the course Commercial Package Program II for students of the academic year 2013-2014 and 2014-2015 academic year can be seen in Table VI.

Increased students absorption of the material taught by lecturers both in the form of lecture notes and instructional videos that can be downloaded students. Improved results of the evaluation of student grades for courses Commerce Package II program for the 2013-2014 school year if compared with the value 
Cite this article as: Marwa Halim and Suharjito , "Learning Management System Development With Application of Asynchronous Learning Method in STMIK IBBI Medan", CommIT (Communication \& Information Technology) Journal 9(2), 83-90, 2015.

of a student for the academic year 2014-2015 after use online learning system is very significant where the average score for 2013-2014 school year students grades is $44 \%$ and the average score for 2014-2015 school year students grades is $60.52 \%$.

In increasing student participation in the online learning process can be seen from the students activity in the discussion forums between lecturers and fellow students or students themselves. With the online learning system, the students are required to do/provide comments or feedback on what materials were thrown by professors or fellow students at least 2 times every meeting, so that the role of students in the learning process has been further enhanced compared to the lecture by the face-to-face method in the classroom where students usually more listen to lecturers. To view a student's participation in providing feedback in the form of comments can be seen in Fig. 5.

In the improvement of self-learning ability of students who have followed the course with an online method can be seen from the students' ability in working on tasks both independent assignment and groups task collected on time. In addition to the discussion forum where faculty provides problems that must be commented by a student makes the student works to find the material that will be used in conducting the discussion in the forums.

TABLE VI

IMPROVEMENT IN THE STUDENT SCORE WITH E-LEARNING MANAGEMENT SYSTEM.

\begin{tabular}{crrrrr}
\hline \multirow{2}{*}{ Grade } & \multicolumn{2}{c}{ Academic Year } & 2013-2014 & & \multicolumn{2}{c}{ Academic Year $2014-2015$} \\
\cline { 2 - 3 } \cline { 5 - 6 } & \# Students & Proportion & & \# Students & Proportion \\
\hline A & 12 & 17.1 & & 24 & 31.6 \\
B & 18 & 26.7 & & 35 & 46.1 \\
C & 19 & 27.1 & & 14 & 18.4 \\
D & 14 & 20.0 & & 1 & 1.3 \\
E & 7 & 10.0 & & 2 & 2.6 \\
Total & 70 & 100.0 & & 76 & 100.0 \\
\hline
\end{tabular}

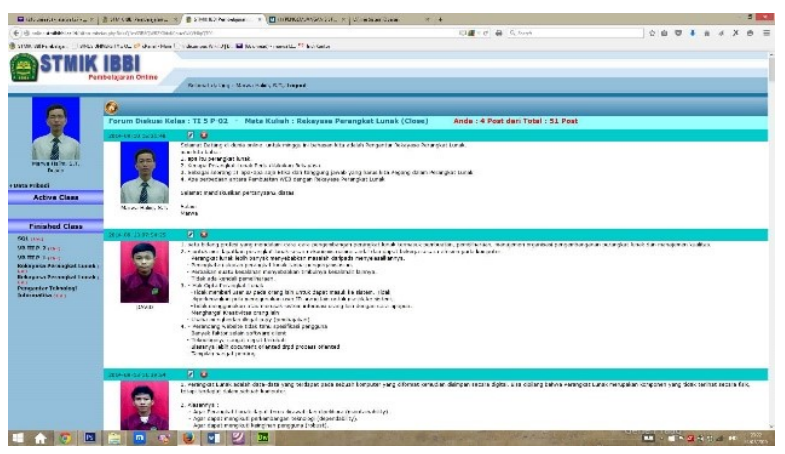

Fig. 5. The example of the discussion on the class forum.
To increase the existing teaching materials on STMIK IBBI with video learning whether screen shots video model or presentation video models of lecturers is additional to new learning models that exist in STMIK IBBI which usually in the form of hardcopy of lecture notes. With the existing instructional videos can help students understand the learning material provided lecturers better due to several advantages that exist in video-based instructional media, among others: Develop students thoughts and opinions; develop imagination; clarify abstract things and provide more realistic explanation; able to act as the primary media to document the social reality that will be dissected in the classroom; and ability to act as a storyteller that can provoke creativity of learners in expressing his ideas.

In developing the instructional video there are several principles that must be observed to produced a good and useful learning videos for quality improvement in teaching and learning.

Pre-learning principle: The beginning of instructional video, students should be informed the purpose and benefits of the modules which lecturers delivered, so that students can mentally self-prepare to understand and is expected to develop materials that will be delivered by lecturers. In the introduction to the instructional video, lecturer deliver the program's objectives complete with initial impressions describes the messages or material to be delivered at each meeting, so that the students minds could picture skills that will be achieved when viewing the initial video and drawn to follow the video until finish.

Modality principle: In the process of multimedia learning, students will learn better if the image appears accompanied by voice the text in the image form. Images and texts seen by the eyes of the students would enter the cognitive system to distract students. By contrast, if students see pictures accompanied by the narration of the lecturer that aims to reinforce understanding since students will fully scrutinize the visual image is reinforced by audio narration.

The principle of fostering generative processing is the combination of personalization, multimedia, sound, and images. In principle, multimedia mention that students will learn better when listening to words (words) simultaneously with the image when compared to the words presented separately. When a student listening to images and narration simultaneously, then the student has the opportunity to build a mental model of visual and verbal concurrently and students are able to make connections between the visual with the verbal. In the media instructional video, every picture to be displayed should be accompanied by an explanatory narrative, so that students have the opportunity to study the video 
Cite this article as: Marwa Halim and Suharjito, "Learning Management System Development With Application of Asynchronous Learning Method in STMIK IBBI Medan", CommIT (Communication \& Information Technology) Journal 9(2), 83-90, 2015.

material visually and verbally, and connect the visual and verbal material to be stored in long term memory.

The principle of personalization: The student comprehension will learn better if learning materials are shown using words in daily conversation narrative form than when using formal language style. This relates to the ability of developers to draw on the words that cause students to feel involved in learning, so as to cultivate the interest of students to listen to the video media until complete. Lecturer as a presenter in the instructional video media is expected to invite students to listen to learning materials so that students feel part of the person in question and converse with a lecturer in video media.

1) At STMIK IBBI, online learning management system should be immediately developed to support online learning. The collected data from stakeholders suggest that the system will greatly beneficial to support learning. Around eightytwo percents believe that the previous system should be enhanced with features supporting online learning. The system should feature instructional video according to $83.2 \%$ respondents and chatting facility according to $82.5 \%$ respondents.

2) At STMIK IBBI, faculties and students have fully aware that the use of information technology in teaching-learning is of importance.

3) The feature of instructional video has been identified to be important to support, particularly, asynchronous method, and it has several advantages of the following:

- Cognitive: Video can be used to study matters relating to students knowledge and intellectual.

- Affective: video program can be used to train elements of emotions, empathy, and appreciation of an activity or situation.

- Psychomotor: video program is appropriate for use in show motion or activity. In the sports field, for example the movements can be easily learned and imitated by the audience.

- In the realm of improving interpersonal competence, the video provides an opportunity for them to discuss what they had seen in congregation.

4. With the development of online learning system by adding video and chatting features on asynchronous learning models that exist in

\section{CONCLUSIONS}

From this study, we draw the following conclusions: STMIK IBBI, students has more freedom in setting learning time and teaching materials that will be provided by the lecturer which can be accessed by students anytime and anywhere besides if the materials are poorly understood, the student can still post a question in a chatting feature that has been provided and lecturers can answer whatever students' question.

\section{REFERENCES}

[1] M. Yazdi, "E-learning sebagai media pembelajaran interaktif berbasis teknologi informasi," Jurnal Ilmiah Foristek, vol. 2, no. 1, pp. 143-152, 2012.

[2] E. Sutanta, "Konsep dan implementasi e-learning (study kasus pengembangan e-learning di sman 1 sentolo yogyakarta)," Jurnal Dasi, vol. 1, no. 1, pp. 1-15, 2010.

[3] E. O. Yılmaz and H. Yurdugül, "The perception of learning in asynchronous online discussions: A scale development study," Procedia-Social and Behavioral Sciences, vol. 83, pp. 776-780, 2013.

[4] J. V. Lineros and M. Hinojosa, "Trends in asynchronous learning," The Global E-Learning Journal, vol. 1, no. 3, pp. 1-10, 2012.

[5] D. Wu and S. R. Hiltz, "Predicting learning from asynchronous online discussions," Journal of Asynchronous Learning Networks, vol. 8, no. 2, pp. 139-152, 2004.

[6] S. Y. Sohn, H. Y. Park, and I. S. Chang, "Assessment of a complementary cyber learning system to offline teaching," Expert systems with applications, vol. 36, no. 3, pp. 6485-6491, 2009.

[7] P. Zaharias and A. Poulymenakou, Handbook of Research on Instructional Systems and Technology. New York: Information Science Reference, 2008, ch. Chapter LIII Design Guidelines for Asynchronous e-learning application, pp. 741-748.

[8] Y.-S. Wang, "Assessment of learner satisfaction with asynchronous electronic learning systems," Information \& Management, vol. 41, no. 1, pp. 75-86, 2003.

[9] A. Fathurohman, "Pengaruh pengembangan model pembelajaran e-learning terhadap prestasi belajar mahasiswa fakultas kedokteran universitas muhammadiyah semarang," Bachelor Thesis, Program Studi Sistem Informasi, Universitas Dian Nuswantoro., 2011. 